\title{
Effect of monocrotaline ingestion on the distribution of protein and angiotensin converting enzyme activity in the rat lung
}

\author{
D J SHALE, M S WISEMAN, W O C M COOKSON \\ From the Osler Chest Unit, Churchill Hospital, Oxford
}

\begin{abstract}
The alveolar accumulation of protein and angiotensin converting enzyme activity was compared with the development of right ventricular hypertrophy in male rats after different periods $\overparen{D}$ of monocrotaline exposure. Total doses of monocrotaline were varied by dividing the animals into three groups in which ingestion was limited to three, seven, and 15 days. These groups were studied $\stackrel{\mathbb{\complement}}{\stackrel{\mathscr{T}}{5}}$ 21 days after the start of monocrotaline exposure and compared with a group treated continuously $\vec{\oplus}$ for 28 days. The total lung weight increased after three or more days of treatment, while after seven $\%$ days there was significant alveolar accumulation of protein, which was paralleled by an increase in angiotensin converting enzyme activity in alveolar lavage fluid. Identical changes also occurred after $\leq$ 15 and 28 days of exposure to monocrotaline. Lung angiotensin converting enzyme activity was $\bar{O}$ decreased after three days' ingestion of monocrotaline and did not alter further with longer periods $\frac{\mathscr{Q}}{\varnothing}$ of exposure. None of these effects of monocrotaline in the three and seven day treatment groups was $\stackrel{\varrho}{\rightarrow}$ associated with right ventricular hypertrophy, which occurred only in animals treated for 15 or $\overrightarrow{0}$ more days. The effects of monocrotaline ingestion on the lung were dose related and had no causal $\frac{3}{5}$ relationship to the development of right ventricular hypertrophy.
\end{abstract}

Exposure to monocrotaline produces acute endothelial injury and the later development of pulmonary hypertension and cor pulmonale in the rat and has been used as a model for studying the pathophysiology of pulmonary vascular disease occurring in man. ${ }^{1-3} \mathrm{~A}$ single subcutaneous dose of monocrotaline $(40-105 \mathrm{mg} / \mathrm{kg})$ will cause alveolar wall interstitial oedema and structural changes in endothelial cells within 24 hours, and a microvascular protein leak that is detectable three days after administration. ${ }^{45} \mathrm{~A}$ causal link has been proposed between this protein leak, which is maximal at seven days, and the development of right ventricular hypertrophy, which usually occurs 10-14 days after parenteral treatment. ${ }^{56}$ The same cardiovascular changes can, however, be induced with cumulative but smaller total doses of monocrotaline administered by the oral route. ${ }^{7-9}$ These regimens have produced a sequence of pulmonary circulatory changes that lead to pulmonary hypertension and right ventricular hyper-

Address for reprint requests: Dr D J Shale, Respiratory Medicine Unit, City Hospital, Nottingham NG5 IPB.

Accepted 7 July 1986 trophy, ${ }^{89}$ but more slowly than after single dose parenteral treatment. ${ }^{69}$

Monocrotaline treatment produces various changes in the metabolic functions of the pulmonary? circulation. ${ }^{6810}$ In single dose studies a reduction in lung angiotensin converting enzyme activity (ACE, EC 3.4.15.1) has been reported to follow the devel-o opment of pulmonary hypertension, and this may represent a regulatory mechanism to control bloodos volume and the increase in pulmonary artery pres- $N$ sure. $^{2611}$ No change in lung ACE activity, however, occurred in rats on low dose oral monocrotaline regi- $\sigma$ mens causing the same pulmonary circulatory changes. ${ }^{81012}$ Thus the change in lung ACE activity might be related to the development of pulmonary hypertension and right ventricular hypertrophy, but might equally be an unrelated effect due to the use of high dose monocrotaline regimens.

We. undertook the present study to define the $\frac{\stackrel{?}{\oplus}}{\circ}$ effects of various oral doses of monocrotaline on the $\frac{}{\sigma}$ evolution of protein accumulation in the alveolus and the distribution of ACE activity in serum, lung, ando alveolar lavage fluid, and on the relationship of these to the development of right ventricular hypertrophy 


\section{Methods}

\section{EXPERIMENTAL PROTOCOL}

Twenty five Sprague-Dawley strain male rats (Medical Research Council), with an initial mean body weight of 90 (SD 14.2) g, received either monocrotaline (Warner Lambert Ltd, USA) in their drinking water $(20 \mathrm{mg} / \mathrm{l} 62 \mu \mathrm{mol} / \mathrm{l})$ or tap water ad libitum. Groups of six or seven animals ingested monocrotaline for three, seven, or 15 days. The effect of treatment was studied at 21 days and compared with a control group receiving water for 21 days. Another group was studied after 28 days of continuous monocrotaline ingestion to provide a high dose control group. All samples were obtained under pentobarbitone anaesthesia $(120 \mathrm{mg} / \mathrm{kg}$ intraperitoneally) (May and Baker Ltd). Blood collected from the inferior vena cava was allowed to clot on ice. The pulmonary circulation was freed of blood by the infusion of $10 \mathrm{ml}$ of ice cold bicarbonate buffered normal saline ( $\mathrm{pH} \mathrm{7.4).} \mathrm{The} \mathrm{lungs} \mathrm{were} \mathrm{then} \mathrm{lavaged} \mathrm{via}$ a tracheal cannula with $5 \mathrm{ml}$ of ice cold buffered saline, which for 30 seconds was repeatedly removed and reinjected. Lungs were removed, blotted dry, and stored with all other specimens at $-20^{\circ} \mathrm{C}$ until analysis. Hearts were fixed in buffered formol saline $\mathrm{pH}$ 7.6) and dissected after four days' fixation. The right ventricular free wall was dissected from the left ventricle at its junction with the septum. The daily ingestion of monocrotaline was monitored by weighing the drinking water bottles of rats kept in groups of four.

\section{ASSAY PROCEDURES}

A weighed portion of lung (about $100 \mathrm{mg}$ ) was homogenised in $2 \mathrm{ml}$ of phosphate buffered isotonic saline (pH 8.3) in a hand held homogeniser. After centrifugation $\left(3000 \mathrm{rev} / \mathrm{min}\right.$ for $\left.30 \mathrm{~min}, 4^{\circ} \mathrm{C}\right)$ the supernatant was collected and the total protein content and ACE activity were measured. Protein was determined by a colorimetric method (Bio Rad Ltd, UK) with bovine serum albumin as the standard. ${ }^{13} \mathrm{~A}$ standard curve was prepared for each assay run. The average interassay variation was $12 \%(4-15 \%$ as coefficient of variation) over the assay standard curve for 12 assays. Angiotensin converting enzyme activity was determined spectrofluorimetrically ${ }^{14}$ with hippuryl-L-histidyl-L-leucine as the substrate (CBC Ltd, UK). For two control sera in 18 assays, the interassay variation was $5.9 \%$ and $8.6 \%$ (as coefficient of variation). Dry weight was determined by drying at $60^{\circ} \mathrm{C}$ until a constant weight was achieved for a preweighed portion of lung.

\section{Statistical methods}

The significance of differences between groups was assessed with an unpaired Student's $t$ test after an F test for the equality of variance. A value of $p$ less than 0.05 was taken to indicate statistical significance. Correlation coefficients and regression lines were calculated from standard formulae. ${ }^{15}$

\section{Results}

\section{MONOCROTALINE INGESTION}

The average intake of monocrotaline solution was $21 \cdot 1(2 \cdot 4) \mathrm{ml} / \mathrm{rat} / \mathrm{day}$, giving an average daily ingestion of $424 \mu \mathrm{g} / \mathrm{rat} / \mathrm{day}$.

\section{ANATOMICAL DATA}

The body weight was significantly reduced only after 28 days of monocrotaline treatment (table 1). The wet weight of the lung increased after three days of treatment, with a significant increase in lung to body weight ratio and parallel increases in total lung protein, dry weight, and water content that were significant after seven days' monocrotaline exposure (table 2), although individual components did not change significantly as a proportion of total lung mass for any exposure period (table 2). Increase in lung mass was separated from the development of right ventricular hypertrophy, which occurred only after 15 days of monocrotaline treatment (tables 1 and 2).

Table 1 Mean (SD) body and heart weights of rats receiving oral monocrotaline

\begin{tabular}{|c|c|c|c|c|c|c|}
\hline & \multicolumn{6}{|c|}{ Days of monocrotaline treatment* } \\
\hline & $C 21$ & 3 & 7 & 15 & 28 & $C 28$ \\
\hline $\begin{array}{l}\text { Final body weight (g) } \\
\text { (SD) } \\
\text { RV/LV +S } \\
\text { (SD) } \\
\text { No/group }\end{array}$ & $\begin{array}{l}226 \\
(14) \\
0 \cdot 31 \\
(0 \cdot 05) \\
6\end{array}$ & $\begin{array}{l}216 \\
(27) \\
0 \cdot 33 \\
(0 \cdot 05) \\
6\end{array}$ & $\begin{array}{l}212 \\
(20) \\
0 \cdot 34 \\
(0 \cdot 05) \\
6\end{array}$ & $\begin{array}{l}206 \\
(25) \\
0 \cdot 43 \dagger \\
(0 \cdot 09) \\
7\end{array}$ & $\begin{array}{l}156 \dagger \\
(42) \\
0.65 \dagger \\
(0.09) \\
4\end{array}$ & $\begin{array}{l}314 \\
(9) \\
0 \cdot 28 \\
(0 \cdot 02) \\
5\end{array}$ \\
\hline
\end{tabular}

${ }^{*} \mathrm{C} 21$ and $\mathrm{C} 28$ are the 21 and 28 day control groups. Animals were studied at 21 days unless stated otherwise.

tp $<0.05$ in comparison with controls.

$\mathrm{RV} / \mathrm{LV}+\mathrm{S}$-ratio of weight of free wall of right ventricle to weight of left ventricle and septum. 


\section{BIOCHEMICAL DATA}

The absolute concentration and lavage to serum (L:S) ratios for protein increased significantly after seven days' monocrotaline treatment (table 3). This was not increased further after 15 days' exposure, although it was after 28 days. The absolute and L:S ACE activity ratio also increased with length of exposure to monocrotaline (table 3 ). There was a significant correlation between total L:S protein and ACE activity ratios ( $r$ $=0.96 ; p<0.001, \mathrm{df} 32$ ). Expression of lavage ACE activity as specific activity of lavage total protein showed a significant reduction after seven and 15 days' monocrotaline ingestion (table 3). Serum ACE등 activity was significantly raised only after 28 days' monocrotaline ingestion, while serum protein concen- $\widehat{\Phi}$ tration was unaffected (table 3). Total lung protein (mg/lung) was significantly increased after seven days' exposure to monocrotaline and was related to $\vec{\circ}$ changes in other components of the lung (table 2). $\overrightarrow{\overrightarrow{.}}$ Hence there was no significant increase in protein per unit of lung. Total lung ACE activity was significantly decreased by three or more days' monocrotaline ${ }^{x}$ treatment (table 4) and was inversely correlated with.lung dry weight $(r=0.74 ; p<0.001, \mathrm{df} 32)$.

Table 2 Mean (SD) weight of lungs and lung components in rats receiving oral monocrotaline

\begin{tabular}{|c|c|c|c|c|c|c|}
\hline & \multicolumn{6}{|c|}{ Days of monocrotaline treatment ${ }^{*}$} \\
\hline & $C 21$ & 3 & 7 & 15 & 28 & $C 28$ \\
\hline $\begin{array}{l}\text { Lung:body weight } \\
\text { Lung weight (mg) } \\
\text { Dry lung weight (mg) } \\
\text { Dry:total weight (\%) } \\
\text { Lung water (mg/lung) } \\
\text { Water:total weight (\%) } \\
\text { Lung protein (mg) } \\
\text { Protein:total weight (\%) }\end{array}$ & $\begin{array}{l}2.48 \\
(0.23) \\
557 \\
(47) \\
82 \\
(6) \\
14.7 \\
(1.2) \\
475 \\
(45) \\
85.3 \\
(1.0) \\
27.9 \\
(3.0) \\
5.1 \\
(0.7)\end{array}$ & $\begin{array}{l}3.09 \dagger \\
(0 \cdot 17) \\
664 \\
(101) \\
87 \\
(14) \\
13.2 \\
(1.2) \\
576 \\
(90) \\
86.8 \\
(1.1) \\
30.6 \\
(6.1) \\
4.6 \\
(0.4)\end{array}$ & $\begin{array}{l}3 \cdot 85 \dagger \\
(0 \cdot 49) \\
814 \dagger \\
(111) \\
115 \dagger \\
(19) \\
14 \cdot 1 \\
(0 \cdot 6) \\
698 \dagger \\
(92) \\
85 \cdot 9 \\
(0 \cdot 5) \\
38 \cdot 2 \dagger \\
(5 \cdot 8) \\
4 \cdot 7 \\
(0 \cdot 4)\end{array}$ & $\begin{array}{l}3.71 \dagger \\
(0 \cdot 38) \\
766 \dagger \\
(99) \\
110 \dagger \\
(16) \\
14 \cdot 4 \\
(1 \cdot 1) \\
655 \dagger \\
(85) \\
86 \cdot 6 \\
(1.0) \\
33 \cdot 4 \dagger \\
(4 \cdot 6) \\
4 \cdot 4 \\
(0.5)\end{array}$ & $\begin{array}{l}6.56 \dagger \\
(2 \cdot 7) \\
940 \dagger \\
(89) \\
115 \dagger \\
(15) \\
12 \cdot 2 \\
(0 \cdot 8) \\
825 \dagger \\
(61) \\
87 \cdot 8 \\
(0.8) \\
36 \cdot 3 \dagger \\
(7 \cdot 1) \\
3.9 \\
(0.7)\end{array}$ & $\begin{array}{l}2 \cdot 16 \\
(0 \cdot 2) \\
675 \\
(64) \\
90 \\
(5) \\
14 \cdot 1 \\
(2 \cdot 0) \\
581 \\
(60) \\
85 \cdot 3 \\
(1 \cdot 7) \\
26 \cdot 6 \\
(1 \cdot 8) \\
4 \cdot 1 \\
(0 \cdot 4)\end{array}$ \\
\hline
\end{tabular}

${ }^{*} \mathrm{C} 21$ and $\mathrm{C} 28$ are the 21 and 28 day control groups.

tp $<0.05$ in comparison with controls.

Table 3 Mean (SD) total protein content and angiotensin converting enzyme (ACE) activity of lavage fluid in rats receiving oral monocrotaline

\begin{tabular}{|c|c|c|c|c|c|c|}
\hline & \multicolumn{6}{|c|}{ Days of monocrotaline treatment ${ }^{*}$} \\
\hline & $C 21$ & 3 & 7 & 15 & 28 & $C 28$ \\
\hline Serum ACE $(\mathrm{nmol} / \mathrm{min} / \mathrm{ml})$ & $\begin{array}{l}102 \cdot 9 \\
(14 \cdot 6)\end{array}$ & $\begin{array}{l}114 \cdot 6 \\
(17 \cdot 5)\end{array}$ & $\begin{array}{l}112.9 \\
(25 \cdot 0)\end{array}$ & $\begin{array}{l}107 \cdot 3 \\
(27 \cdot 9)\end{array}$ & $\begin{array}{l}129 \cdot 7 \dagger \\
(4 \cdot 5)\end{array}$ & $\begin{array}{l}113 \cdot 5 \\
(6 \cdot 4)\end{array}$ \\
\hline Serum protein $(\mathrm{mg} / \mathrm{ml})$ & $\begin{array}{l}43 \cdot 0 \\
(1 \cdot 7)\end{array}$ & $\begin{array}{l}42 \cdot 3 \\
(4 \cdot 0)\end{array}$ & $\begin{array}{l}44 \cdot 7 \\
(1 \cdot 5)\end{array}$ & $\begin{array}{l}44 \cdot 5 \\
(2 \cdot 5)\end{array}$ & $\begin{array}{l}48 \cdot 3 \\
(7 \cdot 4)\end{array}$ & $\begin{array}{l}50.8 \\
(2.9)\end{array}$ \\
\hline $\begin{array}{l}\text { Specific activity serum ACE } \\
\text { (nmol/min } / \mathrm{mg} \mathrm{protein)} \\
\text { Lavage ACE (nmol/min/ml) }\end{array}$ & $\begin{array}{l}2.4 \\
(0.33) \\
0.55 \\
(0.22)\end{array}$ & $\begin{array}{l}2.75 \\
(0.70) \\
0.44 \\
(0.15)\end{array}$ & $\begin{array}{l}2.51 \\
(0.51) \\
1.17 \dagger \\
(0.38)\end{array}$ & $\begin{array}{l}2.41 \\
(0.60) \\
1.11 \dagger \\
(0.50)\end{array}$ & $\begin{array}{l}2.98 \dagger \\
(0.26) \\
2 \cdot 17 \dagger \\
(0.26)\end{array}$ & $\begin{array}{l}2.24 \\
(0.16) \\
0.50 \\
(0.16)\end{array}$ \\
\hline Lavage protein $(\mathrm{mg} / \mathrm{ml})$ & $\begin{array}{l}0.22 \\
(0 \cdot 15)\end{array}$ & $\begin{array}{l}0.20 \\
(0.08)\end{array}$ & $\begin{array}{l}0.78 t \\
(0.34)\end{array}$ & $\begin{array}{l}0.75 t \\
(0.30)\end{array}$ & $\begin{array}{l}i \cdot 44 t \\
(0-24)\end{array}$ & $\begin{array}{l}0.29 \\
(0.06)\end{array}$ \\
\hline $\begin{array}{l}\text { Specific activity of lavage ACE } \\
\text { (nmol/min/mg protein) } \\
\text { Lavage:serum ACE }\left(\times 10^{4}\right)\end{array}$ & $\begin{array}{l}2.47 \\
(0.61) \\
53.8 \\
(18 \cdot 1)\end{array}$ & $\begin{array}{l}2 \cdot 36 \\
(0 \cdot 59) \\
38 \cdot 7 \\
(12 \cdot 4)\end{array}$ & $\begin{array}{l}1.59 \dagger \\
(0.36) \\
106.9 \dagger \\
(30.9)\end{array}$ & $\begin{array}{l}1.53 t \\
(0.57) \\
102.8 \dagger \\
(35.1)\end{array}$ & $\begin{array}{l}1.49 \\
(0 \cdot 10) \\
165 \dagger \\
(30 \cdot 6)\end{array}$ & $\begin{array}{l}1.72 \\
(0.44) \\
43.8 \\
(8.9)\end{array}$ \\
\hline Lavage:serum protein $\left(\times 10^{4}\right)$ & $\begin{array}{l}53 \cdot 2 \\
(32 \cdot 0)\end{array}$ & $\begin{array}{l}48.0 \\
(20.0)\end{array}$ & $\begin{array}{l}176.3 \dagger \\
(69.8)\end{array}$ & $\begin{array}{l}162.7 \dagger \\
(60 \cdot 2)\end{array}$ & $\begin{array}{l}317+t \\
(26 \cdot 0)\end{array}$ & $\begin{array}{l}59.0 \\
(10.0)\end{array}$ \\
\hline
\end{tabular}

Results represent mean and 1 SD for absolute values and for lavage to serum ratios. 
Table 4 Mean (SD) lung angiotensin converting enzyme ( $A C E$ ) activity in rats receiving oral monocrotaline

\begin{tabular}{lllllll}
\hline & \multicolumn{3}{l}{ Days of monocrotaline treatment* } \\
\cline { 2 - 7 } & $C 21$ & 3 & 7 & 15 & 28 & $C 28$ \\
\hline Total lung ACE activity nmol/min/lung & 3852 & 3111 & $2941 \dagger$ & $2948 \dagger$ & 2700 & 3663 \\
Lung ACE activity nmol/min/mg protein & $(282)$ & $(743)$ & $(149)$ & $(463)$ & $(126)$ & $(766)$ \\
& $(10 \cdot 6)$ & $(16 \cdot 2)$ & $(12 \cdot 4)$ & $(16 \cdot 1)$ & $(13 \cdot 4)$ & $(28 \cdot 7)$ \\
\hline
\end{tabular}

*C21 and $\mathrm{C} 28$ are the 21 and 28 day control groups respectively.

tp $<0.05$ in comparison with controls.

\section{Discussion}

Variation of monocrotaline dosage by length of exposure allowed exploration of the temporal relationships of increased lung mass, alveolar protein accumulation, and ACE activity changes to the development of right ventricular hypertrophy. Our rats had an estimated average intake of $424 \mu \mathrm{g}$ monocrotaline/day (equivalent to $2.01 \mathrm{mg} / \mathrm{kg} /$ day) on the basis of the ingestion studies, so that a total dose of $2.97 \mathrm{mg}$ (equivalent to $14.1 \mathrm{mg} / \mathrm{kg}$ ) was found to induce a significant increase in lung mass and alveolar protein accumulation and a reduction of lung ACE activity without the subsequent development of right ventricular hypertrophy. The same daily dose for 15 days (total $6.4 \mathrm{mg}$, equivalent to $30.3 \mathrm{mg} / \mathrm{kg}$ ), however, produced the same changes, but with the addition of right ventricular enlargement. This confirms the advantages of the low dose oral regimen, which allows the demonstration of dose related effects on the pulmonary circulation. 89

The accumulation of protein in the alveoli of rats treated with monocrotaline for seven or more days was presumed to be related to the presence of a microvascular protein leak. ${ }^{45}$ Sugita $e t a^{5}$ induced a protein leak with a single parenteral dose $(40 \mathrm{mg} / \mathrm{kg})$ of monocrotaline. The leak was present after three days, preceded the development of right ventricular hypertrophy by 11 days, and was assumed to have a causal association. An increased permeability to protein was present throughout the 21 days of their study and the authors considered it possible that it was maintained by the raised pulmonary artery pressure. In the present study, however, protein accumulation in the alveolus was a sustained dose dependent effect of monocrotaline and was independent of the development of right ventricular hypertrophy, suggesting that the leak was unlikely to have been maintained by developing pulmonary hypertension. Sugita et $a^{5}$ reported no effect on the alveoli of the leak they demonstrated, because albumin concentration was not raised one and three days after the start of monocrotaline ingestion. Inspection of their data, however, shows small but statistically significant increases in alveolar lavage albumin concentrations at one, seven, 14, and 21 days. Their data therefore are not at vari- ance with our findings of protein accumulation in the alveoli after monocrotaline treatment, although they could not dissociate this from the later development of pulmonary hypertension and right ventricular hypertrophy.

We found differential changes in ACE activity between the circulatory, interstitial, and alveolar compartments of the lung, whereas previously only serum and lung activities have been reported. ACE is likely to have leaked passively into the alveolar space. The parallel change in protein concentration and ACE activity in lavage fluid and the correlation of $L: S$ ratios for ACE and protein supports this. Similar changes in alveolar protein and ACE follow acute injury to the pulmonary endothelium of the rabbit by hyperoxia, ${ }^{16}$ but not after acute bacterial endotoxin injury in the mouse. ${ }^{17}$ Serum ACE activity may rise after acute endothelial injury as a result of release of enzyme into the circulation, with a corresponding fall in lung enzyme activity. ${ }^{1819}$ This mechanism was not, however, active in this study as monocrotaline treatment did not cause a rise in serum ACE activity, except after 28 days' treatment, and the reduction of total lung ACE activity was maintained after monocrotaline treatment had ceased. Possibly the fall in ACE specific activity after seven or 15 days' treatment was due to addition of protein synthesised locally ${ }^{20}$ in response to monocrotaline induced alveolar injury. ${ }^{6} 21$

The reduction of lung ACE activity after only three days of exposure to monocrotaline has not been reported previously. It implies an early direct effect of monocrotaline on the lung independent of the development of pulmonary hypertension. ${ }^{69}$ The sustained reduction of enzyme activity in the lung may be due to several mechanisms. The most obvious explanation is that endothelial ACE content is unchanged and the reduction of ACE activity is apparent rather than real, because of inflammation and hyperplasia in the lung. The inverse correlation between lung dry weight and total or specific activity for lung ACE supports this. Other mechanisms, however, such as a reduction of the pulmonary circulatory surface area secondary to distal pulmonary vascular pruning, may occur after longer treatment periods. ${ }^{9}$ The reduced ability of the pulmonary vascular bed of the rat to generate 
angiotensin II after monocrotaline treatment ${ }^{11}$ also supports this interpretation, but is probably a longer term effect. Kay et $a l^{6}$ reported reduction of ACE activity 10 days after a single $60 \mathrm{mg} / \mathrm{kg}$ dose of monocrotaline, which coincided with a rise in pulmonary vascular resistance and preceded right ventricular hypertrophy. They suggested that this change represented a regulatory mechanism limiting the development of pulmonary hypertension. ${ }^{2611}$ Our findings do not support this hypothesis as the ACE activity of the lung was consistently decreased at monocrotaline doses incapable of inducing right ventricular hypertrophy and preceding pulmonary hypertension.

Reduced lung ACE activity after monocrotaline ingestion confirms the findings of studies using single subcutaneous doses. ${ }^{2610}$ This is at variance with the findings of other workers, who used the same strain of rats and a similar dosage schedule for monocrotaline. ${ }^{810}$ They used a microsomal extract of lung to determine ACE activity, and also argued that lung ACE could not be expressed in terms of protein as this changed in a non-uniform way with lung growth. ${ }^{10} 12$ Inspection of their data shows that lung protein, water, and total weight increased in a proportionate manner. ${ }^{10}$ Hence the lung protein was 0.148 and $0.146 \mathrm{mg} / \mathrm{mg}$ of lung for their control and monocrotaline groups, which is in keeping with our findings.

In summary, small cumulative doses of monocrotaline, incapable of inducing right ventricular hypertrophy, caused a sustained accumulation of protein in the alveolar spaces, increased lung mass, and reduced lung ACE activity. These effects were considered to be due to a dose dependent action of monocrotaline on the pulmonary circulation and the lung, and indicate that alveolar protein accumulation and changes in ACE activity are independent of the development of pulmonary hypertension under the circumstances of the experiments reported here.

We are grateful to Warner Lambert Ltd for the supply of monocrotaline and for financial support. MSW was supported by an award from the Oxford Regional Health Authority. WOCMC is a WA and MG Saw research fellow.

\section{References}

1 Kay JM, Harris P, Heath D. Pulmonary hypertension produced in rats by ingestion of Crotalaria spectabilis seeds. Thorax 1967;22:176-9.

2 Keane PM, Kay JM, Suyama KL, Gauthier D, Andrew $\mathrm{K}$. Lung angiotensin converting enzyme activity in rats with pulmonary hypertension. Thorax 1982;37: 198-204.

3 Kay JM, Smith P, Heath D, Will JA. Effects of pentobarbitone, cinnarizine, and zoxazolamine on the development of right ventricular hypertrophy and hyper-
Shale, Wiseman, Cookson $\stackrel{\overrightarrow{\mathrm{F}}}{\overrightarrow{\mathrm{F}}}$

tensive pulmonary vascular disease in rats treated witho monocrotaline. Cardiovasc Res 1972;10:200-5.

4 Valdivia E, Lalich JJ, Hayashi Y, Sonnad J. Alterations $\overline{\bar{\sigma}}$ in pulmonary alveoli after a single injection of mono- $\vec{\nabla}$ crotaline. Arch Pathol 1967;84:64-76.

5 Sugita T, Hyers TM, Danber IM, Wagner WW, McMurtry IF, Reeves JT. Lung vessel leak precedes $\overrightarrow{-}$ right ventricular hypertrophy in monocrotaline-: treated rats. J Appl Physiol 1983;54:371-4.

6 Kay JM, Keane PM, Suyama KL, Gauthier D. Angiotensin converting enzyme activity and evolution of pulmonary vascular disease in rats with monocrotaline pulmonary hypertension. Thorax 1982;37:88-96.

7 Huxtable R, Paplanus S, Laugharn J. The prevention of $\vec{N}$ monocrotaline induced right ventricular hypertrophy. Chest 1977;71:308-10.

8 Huxtable R, Ciaramitaro D, Eisenstein D. The effect of음 a pyrrolizidine alkaloid, monocrotaline, and a pyrrole,, dehydroretronecine, on the biochemical functions of the pulmonary endothelium. Mol Pharmacol 1978;14: 1189-203.

9 Meyrick B, Gamble W, Reid L. Development of Cro- $\frac{3}{0}$ talaria pulmonary hypertension:hemodynamic and్ㅡㄴ structural study. Am J Physiol 1980;239:H692-702.

10 Lafranconi WM, Huxtable RJ. Changes in angiotensinconverting enzyme activity in lungs damaged by the. pyrrolizidine alkaloid monocrotaline. Thorax 1983;38: 307-9.

11 Keane PM, Kay JM. Lung angiotensin converting enzyme activity in monocrotaline pulmonaryฏ hypertension [letter]. Thorax 1984;39:159-60.

12 Huxtable RJ, Lafranconi WM. Lung angiotensin con-응 verting enzyme activity in monocrotaline pulmonary을 hypertension [letter]. Thorax 1984;39:159-60.

13 Bradford MA. A rapid and sensitive method for the quantitation of microgram quantities of protein util-o ising the principle of protein-dye binding. Anal Biochem 1976;72:248-54.

14 Friedland J, Silverstein E. A sensitive fluorimetric assay ָِ for serum angiotensin-converting enzyme. Am J Clin Pathol 1976;66:416-23.

15 Bradford-Hill A. Principles of medical statistics. London:ف Lancet Publications, 1971.

16 Shasby DM, Shasby SS, Bowman CM, et al. Angiotensin converting enzyme concentrations in the lung음 lavage of normal rabbits and rabbits treated with $D$ nitrogen mustard exposed to hyperoxia. Am Rev을. Respir Dis 1981;124:202-3.

17 Cookson WOCM, Wiseman MS, Shale DJ. Angiotensin converting enzyme and endotoxin induced lung dam- N age in the mouse. Thorax 1985;40:774-7.

18 Hollinger MA, Giri SN, Patwell S, Zuckerman JE, Gorin A, Parsons G. Effect of acute lung injury on angiotensin converting enzyme in serum, lung lavage and을 effusate. Am Rev Respir Dis 1980;121:373-6.

19 Hollinger MA, Patwell SW, Zuckerman JE, Gorin AB, $\stackrel{\mathcal{D}}{+}$ Parsons G, Giri SN. Effect of paraquat on serum angiotensin converting enzyme. Am Rev Respir Dis 1980;121:795-8.

20 Stockley RA. Measurement of soluble proteins in lungब secretions. Thorax 1984;39:241-7.

21 Kay JM, Smith P, Heath D. Electron microscopy of Crotalaria pulmonary hypertension. Thorax 1969;240 511-26. 